\title{
Homenagem a Arlindo Machado
}

\section{Em defesa da televisão ${ }^{1}$}

Edição da entrevista: Amanda Souza de Miranda (USP) 
Em entrevista concedida em 2014 à TV UFSC, veículo da Universidade Federal de Santa Catarina, o professor Arlindo Machado levantou questões sobre a importância "visceral" da televisão no cotidiano das pessoas, inclusive das crianças, o papel e a importância dos críticos e do entretenimento. Falou, também, sobre o seu pensamento acerca da audiência e de como telespectadores de programas mais informativos podem ter uma influência sobre a programação.

Autor de uma vasta obra, que inclui inúmeros artigos e livros como a Ilusão especular (1984), Máquina e imaginário: o desafio das poéticas tecnológicas (1993), A televisão levada a sério (2000), O sujeito na tela (2007), Outros cinemas: formas esquisexóticas de audiovisual (2019), e, Arlindo Machado, falecido em julho de 2020, foi professor, pesquisador, crítico e curador de arte e tecnologia. Atuava no Departamento de Cinema, Rádio e Televisão (CTR) e no Programa de Pós-Graduação em Meios e Processos Audiovisuais (PPGMPA), tendo sido pioneiro na pesquisa sobre televisão e mídias digitais no Brasil².

Em sua obra pioneira, Machado expõe um meio por muito tempo estigmatizado nas pesquisas acadêmicas, mas que, por sua produção, deve ser compreendido de modo amplo, inclusive pelo exercício permanente da crítica. Em trechos editados da sua fala, expressão do período de exibição da entrevista, ele defende inclusive que haja revistas especializadas na programação televisiva, redigidas por grupos de críticos, movimento que podemos perceber também na atual produção em mídias digitais ou redes sociais. O pesquisador, que também foi curador de arte, não deixou de comparar a TV à literatura e ao cinema, por exemplo, lembrando que todos os meios produzem conteúdos variados e ressaltando que até mesmo Godard pode ter sido uma influência às telenovelas.

O material, disponibilizado no YouTube da TV UFSC ${ }^{3}$, foi editado como forma de reconhecimento e homenagem à memória da contribuição teórica do 
professor, que também criticava a ausência de pesquisas que se detivessem aos detalhes da programação na TV - exercício que faz parte dos textos deste dossiê. Machado fez uma defesa da televisão e do seu papel, chamando atenção para aspectos que começavam a se destacar naquela época, como os processos de reinvenção da TV na Internet e a importância da convergência.

O conteúdo foi escolhido também pela sua metalinguagem: na televisão pública, o pesquisador e crítico ensina sobre televisão, abrindo novas possibilidades de diálogos com outras plataformas. Falando de forma acessível, sem academicismos, Machado condensa, em poucos minutos, a importância de se estudar o popular e de se dialogar com o popular sem julgamentos ou preconceitos.

\section{Mito da alienação e papel do crítico}

Eu estudo televisão durante muito tempo. A vulgaridade existe em qualquer meio e também existe na televisão, mas se você vai buscar, se você se preocupa com televisão, se você estuda televisão você vai ver que tem joias raras, preciosidades que são feitas no mundo inteiro, não só no Brasil. Eu não me interesso pela banalidade, eu me interesso pelas coisas criativas, inventivas e muito avançadas que a televisão faz e faz em grande quantidade. Grandes diretores e grandes artistas trabalharam na televisão, que hoje tem um repertório de trabalhos de altíssima qualidade que merecem ser considerados.

A nossa atividade, principalmente a do crítico e do investigador é sinalizar para o que interessa. Sinalizar: "Olha, aqui tem um caminho. Aqui tem gente fazendo coisas que são a televisão do futuro. Por que senão para o que serve a crítica, para que que serve a investigação? É para sinalizar, apontar caminhos".

\section{Alfabetização midiática}

Acho que a televisão deveria ser ensinada nas escolas, porque é um meio tão importante, tão fundamental. Por que se estuda literatura nas escolas e não se estuda televisão, já que a televisão faz parte visceral das nossas vidas? A gente deveria ensinar as crianças desde os primeiros anos como é que se vê 
televisão, como é que se discute televisão e como é que se critica a televisão e, principalmente, como é que se faz televisão. Assim como você tem redação nos primeiros anos de escolaridade, para aprender a ler e escrever, eu acho que também deveria aprender a fazer televisão, porque fazendo você aprende também o que é certo e errado, o que é bom e mau.

Então eu acho que a televisão deveria ser uma matéria: se não for televisão, pelo menos comunicação em geral, que inclui também o jornalismo, o cinema uma disciplina na qual as pessoas aprendam a ter um discurso crítico com relação aos meios desde o início.

\section{Entretenimento}

Eu não sou nem um pouco crítico com relação ao entretenimento. O entretenimento não é necessariamente burro e pode ser uma forma de aprendizado. O ideal seria que todo aprendizado, principalmente nas primeiras fases da vida, fosse gostoso, fosse legal. Por trás do entretenimento tem muita coisa esperta. Você pega, por exemplo, o Chaves, da mexicana Televisa: se você prestar atenção, você vai ver que é uma crítica social muito profunda. Se você prestar atenção, não é só um entretenimento: tem algo a ver não apenas com a sociedade mexicana, mas latino-americana de uma forma geral.

Não sei se foi pensado, se o Bolaños, idealizador desse programa, pensou, mas não é por acaso que tem tanto sucesso. Deve ter algo ali que mexe com as pessoas. Às vezes um programa de entretenimento tão rudimentar tem uma realidade por trás: é uma questão de saber analisar. Aprenda a ler a televisão, não fique só na superfície. A função da crítica é ajudar o espectador a ler de forma mais profunda esses programas, não ficar só no riso superficial.

\section{Audiência massiva}

A questão da audiência é mal resolvida no campo da televisão. A televisão tem a maior audiência, não importa qual programa, os programas de televisão têm uma audiência massiva. Uma vez eu fui à TV Cultura de São Paulo para fazer 
parte de um programa às $20 \mathrm{~h}$, horário nobre, em um programa sobre livros. Aí eu perguntei para o diretor qual era a audiência desse programa. Ele ficou ofendido com a pergunta e disse: "Olha, para dizer a verdade a gente não passa de traço no Ibope". Eu perguntei o que é traço no Ibope e ele falou: "Olha, aqui em São Paulo, é no máximo 200 mil espectadores".

Falei que 200 mil espectadores assistirem um programa sobre livro às 20h é o maior sucesso que você pode imaginar. Já pensou 200 mil pessoas interessadas em discutir os livros que são publicados, em vez de ver a novela ou telejornal? Então eu acho que a televisão trabalha com uma escala de audiência tão elevada que ultrapassa qualquer outro meio. A mais baixa audiência de televisão corresponde ao mais alto público de qualquer outro meio. Imagina um livro que consegue chegar a 200 mil, uma exposição de arte que tem 200 mil espectadores? A televisão consegue isso facilmente.

\section{Influências da audiência}

Eu acho que, portanto, a questão da audiência está mal colocada dentro da discussão de televisão, porque você tem que imaginar também o seguinte: a audiência está numa pirâmide - você tem lá em cima os programas, os filmes, os romances que são mais inovadores, aqueles que arrebentam. Quanto mais forte é a informação, quanto mais radical é a informação, menos público você tem. Mas esse público que você tem é um público formador de opinião, que vai, por sua vez, levar essa informação. Então essa informação radical a que poucos têm acesso vai sendo transmitida dentro da pirâmide.

Eu lembro que nos anos 1960 o Godard fazia uns filmes em que o ator virava para o público e falava com o público do cinema, quebrava a ilusão do cinema. Isso, 20 anos depois, estava na telenovela. Então aquela informação, que em um primeiro momento é muito radical, ela vai descendo e um dia chega na base. 


\section{Caminhos da TV}

Essa é uma discussão que está se fazendo em todos os campos. No cinema também se discute, no livro impresso. Nada vai acabar, mas tudo precisa se transformar, porque o mundo mudou muito. Acho que a televisão está aprendendo isso, porque hoje o espectador foge da televisão, ele não está mais na frente do aparelho de televisão, ele está também na internet, no celular, em outras telas. Se a televisão quiser continuar existindo, ela tem que aprender a conviver com isso.

Eu acho que um grande salto que aconteceu na história de televisão foi uma série norte-americana chamada Lost $^{4}$, que alguns dizem que é o nascimento da televisão 2.0, é a televisão do futuro, porque não acontecia só na televisão, mas nos jornais, no outdoor da rua, na internet. Você não sabe direito o que foi criado pela empresa produtora e o que os fãs fizeram. A comunidade de fãs é uma grande invenção da televisão, porque ultrapassa a imaginação dos próprios produtores. Isso cria uma forma nova de interatividade. O espectador não é mais alguém passivo sentado na frente televisão, ele grava, ele depois assiste em câmera lenta, pega os detalhes que ele quer, congela um fotograma e distribui na internet.

Ao final da entrevista, concedida a Djalma Junior, o professor ainda comenta aspectos relacionados à Web TV, problematizando a mera transposição de linguagem, sem que se pense em ferramentas de interação e convergência. À época, alguns produtos já vinham fazendo seus primeiros ensaios para um novo modelo de televisão, hoje marcado também por plataformas de streaming. Além de toda a sua produção teórica e das entrevistas nas quais discute seu trabalho, Arlindo Machado deixou também legado e afetos entre seus orientandos e colegas de trabalho, que o celebraram em homenagem recente feita pela Escola de Comunicações e Artes da Universidade de São Paulo5 . 